\title{
FERMENTATION PATTERNS IN RABBIT CAECAL CULTURES SUPPLIED WITH PLANT POLYSACCHARIDES AND LACTATE
}

\author{
M. MAROUNEK ${ }^{1}$, S. J. VOVK ${ }^{1 *}$, V. BENDA ${ }^{2}$ \\ ${ }^{1}$ Institute of Animal Physiology and Genetics, Prague, Uhř́něves, ${ }^{2}$ Institute of Chemical Technology, \\ Prague \\ *Present address: Lviv State Agricultural Institute, 292040 Lviv, Dubliany, Ukraine
}

Received September 2, 1996

Accepted February 10, 1997

\begin{abstract}
Marounek M., S. J. Vovk, V. Benda: Fermentation Patterns in Rabbit Caecal Cultures Supplied with Plant Polysaccharides and Lactate. Acta vet. Brno 1997, 67:9-13.

Fermentation patterns were investigated in anaerobic cultures of the rabbit caecal contents supplied with starch, hemicellulose, pectin, inulin and sodium lactate. Pectin and inulin were fermented more rapidly than starch and hemicellulose. Fermentation of pectin produced the highest amount of fermentation gas. The highest molar proportion of acetate was found in volatile fatty acids (VFA) of cultures supplied with pectin or without substrate. The highest molar proportions of propionate, butyrate and caproate were found in cultures supplied with inulin, sodium lactate and starch, respectively. Acetate and butyrate accounted for 68 - $85 \%$ of metabolite carbon. Low proportions of propionate and valerate were specific for all substrates. The production of methane was roughly proportional to the VFA production (one mol of methane per 5.9-7.3 mols of VFA). Hydrogen recovery values varied from 50.5 to $61.0 \%$, suggesting the presence of $\mathrm{H}_{2}$ - dependent acetogenesis.
\end{abstract}

Rabbit, caecum, fermentation, VFA production, in vitro cultures

The rabbit caecum is a fermentative chamber, where the microorganisms of the gut are able to metabolically alter the unabsorbed digesta from the stomach and small intestine, making it available to the host. The rabbit caecum is colonized by an abundant bacterial flora, $c a 10^{10}$ cultivable cells per $1 \mathrm{~g}$ (Forsythe and Parker 1985). The principial substrates for caecal microorganisms are polysaccharides (hemicellulose, pectin, starch) and protein. Polysaccharides are converted to volatile fatty acids (VFA), methane, carbon dioxide and compounds incorporated into bacterial cells. The VFA are absorbed, supplying additional energy for the host.

Broiler rabbits fed high concentrate diets are highly susceptible to the development of digestive disturbances. Weanling rabbits are particularly sensitive. High mortality of young rabbits has severe economic impact on commercial rabbit production. The ethiology of digestive disturbances is multifactorial. It is known, however, that apart from specific pathogenic agents, the proliferation in the caecum of bacteria that produce potent toxins is responsible for the major part of losses (Cheeke 1989). Cheeke and Patton (1980) proposed that enterotoxemia was caused by carbohydrate overload in the hindgut, providing a substrate allowing the proliferation of pathogens. On low fibre diets, hypomobility occurs, resulting in prolonged retention time of digesta in the caecum, changes in caecal $\mathrm{pH}$, and ultimately causing changes in the caecal microbial population. On the other hand, it has been shown that caecal VFA and low pH inhibit pathogen's proliferation in the caecum (Prohászka 1980). It follows from these facts that the caecal digestion is one of the factors limiting rabbit performance. The aim of this study was to obtain more information on rabbit caecal fermentation pattern. We compared production of microbial metabolites (VFA, gas, methane), in in vitro cultures of the rabbit caecal contents supplied with starch, hemicellulose, pectin, inulin and lactate. 


\section{Materials and Methods}

Rabbits were New Zealand $\times$ Californian hybrids, fed ad libitum a commercial granulated feed, containing $(\%)$ : barley - 18.5, oat - 10.0, wheat bran - 20.0, dehydrated lucerne - 25.0, sunflower meal - 21.0, soya-bean meal - 2.0 , vitamin-mineral supplement -3.5 . The feed contained no coccidiostat. Twenty rabbits were killed at the age of 80 days, $\mathrm{ca}+\mathrm{h}$ after the morning feeding. Their caeca were emptied by gentle squeezing and pooled caecal contents were used for inoculation of in vitro cultures.

Eight-hour incubations were carried out, on a water bath at $39^{\circ} \mathrm{C}$, in $0.5 \mathrm{I}$ bottles, hermetically closed with rubber stoppers. The caecal contents $(50 \mathrm{ml})$ were diluted with $100 \mathrm{ml}$ of phosphate-bicarbonate buffer (McDougall, 1949). containing isonitrogenous amounts (total $0.5 \mathrm{~g} \mathrm{~N} / \mathrm{l}$ ) of urea and yeast extract from Saccharomyces cerevisiae. Hemicellulose and maize starch were added at $3 \mathrm{~g}$, pectin, inulin, and sodium lactate at $2 \mathrm{~g}$ per incubation. Hemicellulose was isolated from wheat straw (Marounek et al. 1988), the other substrates were purchased. As a control, the caecal contents were incubated under identical conditions without addition of the substrate. Each experimental or control arrangement was incubated in four replicates. Cultures were agitated manually every $30 \mathrm{~min}$. To provide anaerobiosis, addition of sodium sulphide to the incubation fluid $(0.5 \mathrm{~g} / \mathrm{l})$ and $\mathrm{CO}_{2}$ atmosphere were used. The $\mathrm{pH}$ fell from ca 7.1-7.2 to about 5.5-6.3 after incubation.

Total VFA were estimated by titration, after steam distillation. Their molar composition was determined by gasliquid chromatography, at $140^{\circ} \mathrm{C}$, using a $2.4 \mathrm{~m}$ column of Supelcoport with $5 \%$ FFAP (Supelco). Samples of the headspace gas were taken at the end of the incubation and analysed using the same gas chromatograph with FID detector. At the same time, the manometric pressure in incubation vessels was measured. Methane production was calculated as the product of methane concentration and total gas production. The gas absorption chromatography was employed for the $\mathrm{H}_{2}$ determination on the Carbosieve $\mathrm{S}$ column (Supelco) and a TCD detector. Metabolic hydrogen recovery (R) was computed according to Demeyer and V an Nevel (1975). The following equations were used:

$$
\begin{aligned}
& \mathrm{R}=2 \mathrm{H}_{\text {accepted }} / 2 \mathrm{H}_{\text {released }} \\
& 2 \mathrm{H}_{\text {accepted }}=4 \mathrm{M}+2 \mathrm{P}+2 \mathrm{~B}+4 \mathrm{~V}+4 \mathrm{C} \\
& 2 \mathrm{H}_{\text {released }}=2 \mathrm{~A}+\mathrm{P}+4 \mathrm{~B}+3 \mathrm{~V}+6 \mathrm{C},
\end{aligned}
$$

where M. A, P, B, V and C are molar productions of methane, acetate, propionate, butyrate, valerate and caproate, respectively. The results summarized in tables are related to a difference between the beginning and the end of the incubation. The net amounts produced were obtained by correction of amounts determined for amounds present before incubation. The statisticial treatment of the data was performed by one factorial analysis of variance.

\section{Results and Discussion}

Table 1 shows that pectin and inulin were fermented more rapidly in in vitro incubations of the rabbit caecal contents than other substrates tested. Production of VFA from starch and hemicellulose was markedly lower, if we take into account the fact that these substrates were supplied in higher amounts at the beginning of the incubation. Approximately one half of the VFA production originated from the fermentation of carbon sources present in inocula. In all cultures, the propionate percentages were higher than the average proportion of propionate in the caecal contents used for inoculation. The average dry matter (\%), $\mathrm{pH}$ and VFA concentration $(\mathrm{mmol} / \mathrm{l})$ in the rabbit caecal contents were 24.1, 6.57 and 62.5 , resp. Acetate, propionate, butyrate, valerate, caproate represented on average $71.5,7.9,17.2,1.9$ and $1.5 \mathrm{~mol} . \%$ of total VFA, respectively. The highest molar proportion of acetate was observed in cultures supplied with pectin or without substrate. The addition of any fermentable substrate to the caecal cultures changed the fermentation stoichiometry towards less acetate and more butyrate and caproate (in comparison with substrate-free controls). The highest molar percentages of propionate, butyrate and caproate were found in cultures supplied with inulin, sodium lactate and starch, respectively. Lactate is produced by some strains of caecal bacteria. It should be mentioned that in the rumen, acetate and propionate, not butyrate, are main products of the lactate fermentation (Nakamura and Takahashi 1971). Fermentation of pectin produced the highest volume of the fermentation gas, probably because of $\mathrm{CO}_{2}$ formed in uronate decarboxylation. The production of methane was roughly proportional to the VFA production. Between 5.9 and 7.3 mols of VFA per mol 
Table 1

Production of VFA, fermentation gas and methane in in vitro incubations of the rabbit ceacal contents supplied with plant polysaccharides and lactate

\begin{tabular}{|l|cccccc|}
\hline \multirow{2}{*}{ Parameter } & \multicolumn{5}{|c|}{ Substrate } \\
\cline { 2 - 7 } & Starch $^{1}$ & Hemicellulose $^{1}$ & Pectin $^{2}$ & Inulin $^{2}$ & Na-lactate & $-^{3}$ \\
\hline Total VFA (nmol/flask) & $11.33^{\mathrm{a}}$ & $13.25^{\mathrm{b}}$ & $14.82^{\mathrm{bc}}$ & $14.88^{\mathrm{c}}$ & $9.98^{\mathrm{ad}}$ & $6.68^{\mathrm{e}}$ \\
& $(0.56)$ & $(0.58)$ & $(1.48)$ & $(0.75)$ & $(0.80)$ & $(0.59)$ \\
Acetate (\%) & $66.0^{\mathrm{a}}$ & $69.4^{\mathrm{a}}$ & $71.2^{\mathrm{ab}}$ & $64.9^{\mathrm{ac}}$ & $60.5^{\mathrm{ad}}$ & $74.3^{\mathrm{b} \mathrm{c}}$ \\
& $(5.5)$ & $(1.2)$ & $(2.1)$ & $(3.1)$ & $(6.7)$ & $(1.2)$ \\
Propionate (\%) & $9.5^{\mathrm{a}}$ & $11.1^{\mathrm{b}}$ & $8.3^{\mathrm{c}}$ & $13.0^{\mathrm{bd}}$ & $12.2^{\mathrm{bd}}$ & $14.5^{\mathrm{de}}$ \\
& $(0.6)$ & $(0.9)$ & $(0.4)$ & $(1.0)$ & $(0.3)$ & $(0.7)$ \\
Butyrate (\%) & $17.2^{\mathrm{a}}$ & $17.3^{\mathrm{a}}$ & $17.4^{\mathrm{a}}$ & $18.7^{\mathrm{a}}$ & $23.0^{\mathrm{a}}$ & $8.8^{\mathrm{b}}$ \\
& $(2.8)$ & $(1.0)$ & $(0.7)$ & $(1.8)$ & $(5.2)$ & $(1.1)$ \\
Valerate (\%) & $2.5^{\mathrm{a}}$ & $1.4^{\mathrm{a}}$ & $1.5^{\mathrm{a}}$ & $1.7^{\mathrm{a}}$ & $2.3^{\mathrm{a}}$ & $1.9^{\mathrm{a}}$ \\
& $(0.9)$ & $(0.1)$ & $(0.1)$ & $(0.6)$ & $(0.7)$ & $(0.5)$ \\
Caproate (\%) & $4.8^{\mathrm{a}}$ & $0.8^{\mathrm{b}}$ & $1.6^{\mathrm{c}}$ & $1.7^{\mathrm{c}}$ & $2.0^{\mathrm{cd}}$ & $0.5^{\mathrm{be}}$ \\
Total gas (ml/flask) & $(2.1)$ & $(0.1)$ & $(0.3)$ & $(0.5)$ & $(0.6)$ & $(0.3)$ \\
& $373^{\mathrm{a}}$ & $365^{\mathrm{a}}$ & $548^{\mathrm{b}}$ & $447^{\mathrm{c}}$ & $188^{\mathrm{d}}$ & $179^{\mathrm{d}}$ \\
Methane (mmol/flask) & $(38)$ & $(36)$ & $(10)$ & $(25)$ & $(30)$ & $(22)$ \\
VFA/methane (mol/mol) & $1.92^{\mathrm{a}}$ & $2.00^{\mathrm{a}}$ & $2.02^{\mathrm{a}}$ & $2.11^{\mathrm{a}}$ & $1.45^{\mathrm{b}}$ & $1.08^{\mathrm{c}}$ \\
2H-recovery (\%) & $(0.11)$ & $(0.12)$ & $(0.17)$ & $(0.09)$ & $(0.08)$ & $(0.06)$ \\
& 5.90 & 6.63 & 7.34 & 7.05 & 6.88 & 6.19 \\
& 61.0 & 55.2 & 50.5 & 57.4 & 59.7 & 58.4 \\
\hline
\end{tabular}

Means of four incubations $\left(8 \mathrm{~h} / 39^{\circ} \mathrm{C}\right)$. Standard deviations are given in parentheses beneath the mean values $13 \mathrm{~g} / 150 \mathrm{ml}$

$22 \mathrm{~g} / 150 \mathrm{ml}$

${ }^{3}$ Without substrate

a-e Values within the same row differ if they do not share a common superscript $(\mathrm{P}<0.05)$

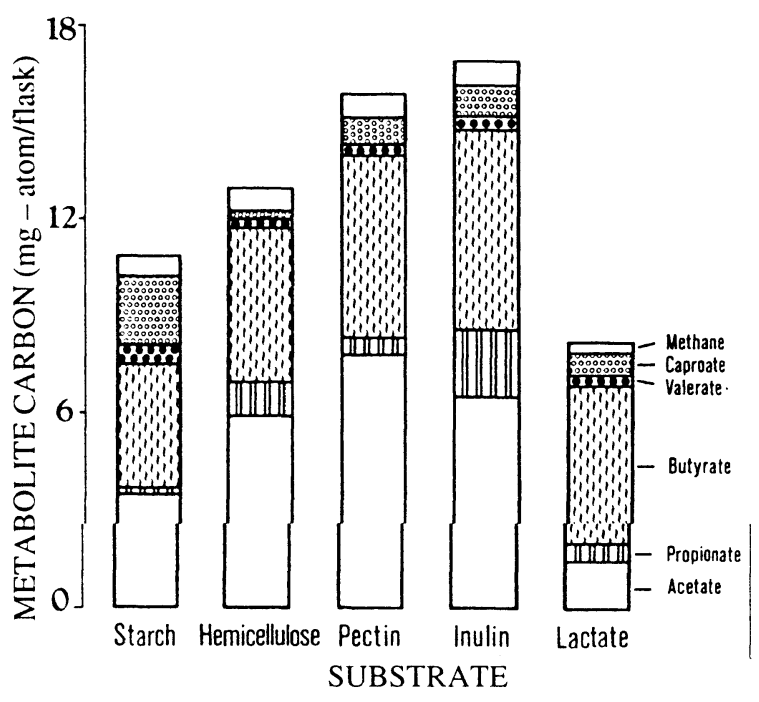

Fig. 1. Distribution of metabolite carbon in in vitro incubations of the rabbit caecal contents supplied with plant polysaccharides and lactate of methane were produced. Corresponding values found in the rumen contents varied from 3:1 to 4:1 (Baldwin et al. 1970). Hydrogen recoveries were low in rabbit caecal cultures (range 50.5-61.0 \%), indicating the presence of acetogenesis from $\mathrm{CO}_{2}$ and $\mathrm{H}_{2}$. Acetate production by $\mathrm{H}_{2}$-dependent $\mathrm{CO}_{2}$ reduction in the rabbit caecum was demonstrated by Prins and Lankhorst (1977). The headspace gas contained $<0.1 \%$ ( $v / v)$ of $\mathrm{H}_{2}$.

The VFA and methane productions corrected for the amounts produced in the absence of added substrate are presented in Fig. 1. The data are expressed as metabolite carbon, in $\mathrm{mg}$-atoms 
C per incubation. Acetate and butyrate accounted for 67.6-84.8 \% of metabolite carbon. Other metabolites were quantitatively less important. The predominance of acetate and butyrate and low proportion of propionate were specific for all substrates.

It has been shown in rabbits that caecal VFA levels depend on the age of animals (Piattoni et al. 1995), on the time after feeding (Gidenne and Bellier 1992) and on dietary composition. Hoower and Heit mann (1972) found that an increased dietary fibre level did cause an increase in caecal VFA concentration, which was mainly attributable to butyric acid. The caecal butyrate production was greater than that of propionate, which represents a divergence from the fermentation ratios normally found in the rumen of ruminants. Gidenne (1992) related the VFA level and acetate proportion to the cell wall contents of the feed. It is shown in this study that four plant polysaccharides and lactate are fermented at different rates in in vitro incubations of the rabbit caecal contents and differ in proportions of fermentation end-products. Substrate-induced fermentation shifts, however, seem to be less pronounced than those in cultures of mixed rumen microorganisms (Leedle and Hespell 1983). This difference probably reflects more uniform composition of rabbit caecal microflora in comparison with that of the rumen.

\section{Fermentace rostlinných polysacharidů a laktátu v kulturách obsahu slepého střeva králíků}

Fermentace $\mathrm{v}$ slepém střevu má vztah $\mathrm{k}$ užitkovosti králíků i jejich zdravotnímu stavu. Zjištovali jsme parametry fermentace při anaerobních inkubacích obsahu slepého střeva se škrobem, hemicelulózou, pektinem, inulinem a Na-laktátem. Pektin a inulin byly fermentovány střevním obsahem snáze než škrob a hemicelulóza. Při fermentaci pektinu se uvolňovalo největší množství fermentačního plynu. Nejvyšší molární zastoupení acetátu bylo zjištěno mezi těkavými mastnými kyselinami (TMK) v kulturách střevního obsahu s pektinem či bez substrátu. Nejvyšší molární zastoupení propionátu, butyrátu a kaproátu bylo nalezeno v inkubacích s inulinem, laktátem a škrobem. Většina (68-85\%) uhlíku vzniklých metabolitů byla obsažena $v$ acetátu a butyrátu. Nízká produkce propionátu a valerátu byla zjištěna u všech substrátů. Produkce metanu byla zhruba úměrná produkci TMK (mol metanu na 5,9-7,3 molu TMK). Hodnoty recovery vodíku se pohybovaly mezi 50,5 a 61,0\%, což naznačuje prítomnost acetogeneze $\mathrm{z} \mathrm{CO}_{2} \mathrm{a} \mathrm{H}_{2}$.

\section{References}

BALDWIN, R. L., LUCAS, H.L., CABRERA, R. 1970: Energetic relationships in the formation and utilization of fermentation end-products. In: Physiology of Digestion and Metabolism in the Ruminant, pp. 319-334, Oriel Press, Newcastle upon Tyne

CHEEKE, P. R. 1989: Rabbit nutrition: A quiet growth area with great potential. In: Animal Feeds: Biological Additives. Proceedings No 119, 249 -260, University of Sydney

CHEEKE, P.R., PATTON, N. M. 1980:Carbohydrate-overload of the hindgut: A probable cause of enteritis. J. Appl. Rabbit Res. 3:20

DEMEYER, D.I., VAN NEVEL, C.J. 1975: Methanogenesis, an integrated part of carbohydrate fermentation, and its control. In: Proc. IVth Int. Symp. Rumin. Physiol., pp. 366-382, Univ. New England Publ. Unit, Armidale, Australia

FORSYTHE, S. J., PARKER, D. S. 1985: Nitrogen metabolism by the microbial flora of the rabbit caecum. J. Appl. Bacteriol. 58:363-369

GIDENNE, T. 1992: Digestion des constituants pariétaux et activité fermentaire caecale chez le lapin en croissance: incidence du taux d'incorporation et de la granulométrie de la source de fibre. Ann. Zootech. 41:33-34

GIDENNE, T., BELLIER, R. 1992: Étude in vivo de l'activité fermentaire caecale chez le lapin. Mise au point et validation d'une nouvelle technique de canulation caecale. Reprod. Nutr. Dev. 32:365-376

HOOVER, W. H., HEITMANN, R. N.: Cecal nitrogen metabolism and amino acid absorption in the rabbit. J. Nutr. 105:245-252 
LEEDLE, J. A. Z., HESPELL, R. B. 1983: Brief incubations of mixed rumen bacteria: Effect of anaerobiosis and sources of nitrogen and carbon. J. Dairy Sci. 66:1003-1014

MAROUNEK, M., KOPEČNÝ, J., BARTOŠ, S., BŘEZINA, P. 1988: Isolation of wheat cellulose and hemicelluloses for in vitro studies on ruminal digestion. Sci. Agric. Bohem. 20:189-192

McDOUGALL, E. I. 1949: Studies on ruminant saliva I. The composition and output of sheep's saliva. Biochem. J. 43:99-106

NAKAMURA, K., TAKAHASHI, H. 1971: Role of lactate as an intermediate of fatty acid fermentation in the sheep rumen. J. Gen. Appl. Microbiol. 17:319-328

PIATTONI, F., MAERTENS, L., DEMEYER, D. 1995: Age dependent variation of caecal composition of young rabbits. Arch. Anim. Nutr. 48:347-355

PRINS, R. A., LANKHORST, A. 1977: Synthesis of acetate from $\mathrm{CO}_{2}$ in the cecum of some rodents. FESM Microbiol. Lett. 1:255-258

PROHÁSZKA, L. 1980: Antibacterial effect of volatile fatty acids in enteric E.coli-infections of rabbits. Zbl. Vet. Med. B 27:631-639

Address for correspondence:

Doc. Ing. M. Marounek, DrSc.

Institute of Animal Physiology and Genetics

10400 Prague 10 - Uhříněves

Czech Republic

Phone: 420267711731

Fax: 420267710803 